Northwestern University School of Law Northwestern University School of Law Scholarly Commons

Faculty Working Papers

1970

\title{
Manifest Intent and the Generation by Treaty of Customary Rules of International Law
}

Anthony D'Amato

Northwestern University School of Law, a-damato@law.northwestern.edu

\section{Repository Citation}

D'Amato, Anthony, "Manifest Intent and the Generation by Treaty of Customary Rules of International Law" (1970). Faculty Working Papers. Paper 128.

http://scholarlycommons.law.northwestern.edu/facultyworkingpapers/128 


\title{
Manifest Intent and the Generation by Treaty of Customary Rules of International Law,
} by Anthony D'Amato*, 64 A.J.I.L 892-902 (1970)

\begin{abstract}
I shall argue in this essay that the World Court used a method which might be called the rule of manifest intent in the North Sea Continental Shelf Cases, that this method differs from a more traditional approach found in the writings of publicists, and that this new method accords well with the growing need to objectify and place upon a scientific basis the methodology by which one may determine what in fact are the rules of customary law.
\end{abstract}

Tags: Customary International Law, Norm-creation by Treaty, Manifest Intent Rule, Continental Shelf Convention, North Sea Continental Shelf Cases, Equidistance Principle

[pg892]** The World Court's recent decision in the North Sea Continental Shelf Cases FN1 is a major contribution to that branch of the theory of customary international law dealing with norm-creation by means of a treaty. The Court articulated a new methodology for determining which provisions in treaties can form the basis of universally binding customary law. As the spreading network of international conventions becomes more fine-meshed, the substantive rules of international customary law may be expected to conform more and more closely to the provisions in these conventions. The World Court has implicitly recognized this process in many prior opinions, but it was not until the Continental Shelf decision that the link between treaty and custom was focused upon with precision. I shall argue in this essay that the Court used a method which might be called the rule of manifest intent, that this method differs from a more traditional approach found in the writings of publicists, and that this new method accords well with the growing need to objectify and place upon a scientific basis the methodology by which one may determine what in fact are the rules of customary law.

\section{THE BASIS FOR THE CONTINENTAL SHELF DECISION}

Courts do not announce methodological procedures in a vacuum; rather, a specific decision is the agency which gives life and shape to methods of legal analysis. The North Sea Continental Shelf Cases presented a very special kind of problem which perforce colored the Court's analytical methods. At the heart of the dispute was whether the concept of equidistanceFN2 is internationally required as determining the legal shares in the North Sea of the adjacent coastal states, Denmark, Federal Republic of Germany, and The Netherlands. This concept was given expression in Article 6, paragraph 2, of the 1958 Geneva Convention on the Continental Shelf,FN3 a multilateral convention among 39 states, including Denmark and The Netherlands but not including the Federal Republic, which disputes the equidistance concept.FN4 As the Court immediately pointed out, an equidistance line between two adjacent states extending into a body of water [pg893] divides the water roughly equally for the states so long as their coastlines are straight or nearly straight. But where one coastline is concave or recessing, then an equidistance line between the concave state and the straight state would disproportionately favor the latter, cutting off the former's access to the body of water and the subjacent seabed.FN5 Since the Federal Republic's coast is concave to both the adjacent states-Denmark and The Netherlands - an equidistance line would meet at the apex of a triangle at a relatively short distance from the Federal Republics coast, "cutting off" any further areas of the continental shelf beyond this triangle.FN6 But this method as applied to Germany would, in the Court's words, produce "results that appear on the face of them to be 
extraordinary, unnatural or unreasonable,"FN7. The Court added in plain and certain terms: "It is basically this fact which underlies the present proceedings."FN8

The Federal Republic had indeed signed the 1958 Convention, although it never ratified. Was it aware at the time of signing of what Article 6, paragraph 2, would accomplish in its own case? Probably not; the Court says that the Federal Republic's various declarations concerning the convention as well as its signing of the convention were done "before becoming fully aware of what the probable effects in the North Sea would be." FN9 Moreover, if the real party in interest, that is, the party with the concave coast, was asleep at the switch for many years with respect to the effect of the equidistance concept, it is likely that the framers of the 1958 Convention themselves did not know that it would produce "extraordinary, unnatural or unreasonable" effects in the unanticipated situation of a concave coast. This is indeed in part the Court's conclusion after examining the travaux preparatoires; no one ever mentioned the idea of a concave coast, and thus the equidistance concept was probably not intended explicitly to cover such a situation. On the other hand, there were indications in the travaux that in certain cases "the geographical configurations of the coast would render a boundary drawn on [the equidistance] basis inequitable,"FN10 For this latter reason, Article 6, paragraph 2, was framed with deliberate qualifications so that the equidistance concept at least did not stand out as the unalloyed rule in all cases. Thus, on either argument, the Court was able to find that it certainly was not the clear intent of the treaty provision to require the application of the equidistance principle in the extraordinary case of a concave coast.

Thus far the Court's opinion, treating Article 6, paragraph 2, as it would a statute, espouses a liberal interpretation where a literal one would be inequitable. The situation recalls the fictional case of the Speluncean Explorers, in which Professor Fuller has a court read in the word "not," which had been omitted from a statute through errors of the successive draftsmen and sponsors of the legislation; without that word, the final clause of the statute would have reached an absurd result.FN11 However, [pg894] the World Court could not carry this statutory approach too far, inasmuch as the Federal Republic was not a party to the 1958 Convention. The words of the convention thus could not be binding in all their particularity upon the Federal Republic.

Accordingly, the Court had to look at customary international law, binding upon all states. In doing so, the Court would not be construing Article 6, paragraph 2, in a way that would be authoritative to the parties to the convention, but rather had to examine the impact of that article upon the general fabric of customary law. Nevertheless, the Court was animated by the same consideration that would have led to a liberal interpretation of the article had the Federal Republic been a party: that the equidistance concept would lead to an unnatural and inequitable result for that state.FN12 The Court thereupon proceeded to show that Article 6 neither stood for nor generated a rule of customary international law binding upon all states, including the Federal Republic.

\section{THE RULE OF MANIFEST INTENT}

At this point the Court was faced with essentially three possibilities: First, it would be logically possible to say that conventional law is totally separate from customary law, and thus 
that provisions in treaties are irrelevant to non-parties. Although possible, such a position would fly in the face of the massive weight of practice to the contrary.FN13 Second, the Court could investigate an emerging rule of customary law in parallel to but en dehors the treaty, to which the treaty provision on equidistance merely provided some kind of corroborative evidence. This approach, to which the Court devoted some time, will be examined later in the present essay. Third and lastly, FN14 the Court could and did evolve a methodological rule that looks to the manifest, rather than the actual or subjective, intent of the treaty itself in determining whether any provision in the treaty "generates" customary international law.FN15

In exploring the third possibility and rejecting the first, the Court for the first time gave explicit, and indeed overwhelming, substantiation to the thesis that provisions in treaties can generate customary law, that they [pg895] can be of a "norm-creating character."FN16 There is no doubt, as the Court put it, that the norm-creating process "is a perfectly possible one and does from time to time occur: it constitutes indeed one of the recognized methods by which new rules of customary international law may be formed."FN17 The Court capped the point by citing the first three articles of the Continental Shelf Convention as having a norm-creating character.FN18 These articles, inter alia, defined the seaward extent of the continental shelf, recognized the coastal state's sovereign rights of exploration and exploitation, spelled out the nature of the rights exercisable and the kind of natural resources involved, and preserved the legal status of superjacent waters as high seas and the legal status of the airspace above the waters.

But if some provisions in treaties are capable of generating customary law binding upon non-parties, clearly there are other types of provisions which do not do so. Provisions spelling out barters and exchanges of goods, for instance, would not be generalizable as legal rules for all states; the same may be true for provisions analogous to special customary law.FN19 As the Court put it, the basic test is whether the provision concerned "should, at all events potentially, be of a fundamentally norm-creating character such as could be regarded as forming the basis of a general rule of law."FN20

The equidistance principle, in the abstract, could be generalizable as a rule of law.FN21 The question then becomes: Has the 1955 Convention itself expressed the equidistance principle in such a form as to manifest the convention's intent to have that principle generate a rule of customary law to the same effect? To answer this question, the Court tells us to look at the form in which the rule is cast as well as the structural relation, within the treaty of the rule to other provisions in the convention. The form and structure, in short, may reveal whether the provision in question may be deemed to have generated a customary rule of law. Importantly, the Court makes no suggestion that the travaux are relevant to this determination. In other words, the actual intent of the framers of the convention or of the subsequent adherents is irrelevant. All that matters with respect to the question whether a treaty provision generates customary law, once we pass the basic test mentioned previously, is what we can infer from the face of the treaty. If the treaty manifests an intent to have a particular provision create customary law, that manifested intent is controlling. (Of course, other sources of law may rebut the ensuing rule; we are concerned here solely with that aspect of the proof of customary law which may be derived from a treaty.) 
Looking first at the form of Article 6, paragraph 2, the Court found several reasons why it was manifestly the intent of the convention not to [pg896] have this particular provision generate a customary norm. The section reads:

Where the same continental shelf is adjacent to the territories of two adjacent states, the boundary of the continental shelf shall be determined by agreement between them. In the absence of agreement, and unless another boundary line is justified by special circumstances, the boundary shall be determined by application of the principle of equidistance from the nearest points of the baselines from which the breadth of the territorial sea of each state is measured.FN22

The Court made several observations, some not lacking in subtlety, on these words. First, the Court noted that the equidistance principle comes after a primary obligation to effect delimitation by agreement. This in itself casts doubt on any alleged intent of the treaty to make the equidistance principle a rule of international law, since normally rules of law would not be prefaced by an exhortation to agreement. Of course, as the Court pointed out, rules of law normally may be departed from in particular cases or between particular parties, but this is a principle that is understood yet not expressed in most formulations of rules of law. And even this principle might be qualified in an abnormal case: the Court briefly raised the issue of jus cogens. This mere hint of the concept of jus cogens conceals an interesting argument in further support of the Court's result. Whether peremptory rules of international law exist, and if so by what method do ordinary rules ascend to such status, is of course a matter of considerable current debate.FN23 But since the possibility of such rules exists, it is correspondingly not impossible that any given international rule, even the equidistance principle itself, might some day rise to the status of a rule of jus cogens. But if such a development were to take place en dehors the 1958 Geneva Convention, then that convention itself would contain a contradiction in its Article 6, paragraph 2. For that article, by making agreement a primary obligation and placing the equidistance principle in secondary status, would be incompatible with the possibility of equidistance as a rule of jus cogens. Since the convention does not consciously on its face deal with such a result, a better inference to draw is that there was no manifested intent to make the equidistance principle a rule of law at all.

A second category of formal objection to Article 6, paragraph 2, lies in the "part played by the notion of special circumstances relative to the principle of equidistance."FN24 The Court did not examine what this relationship was, and it contented itself with simply alluding to the "very considerable, still unresolved controversies as to the exact meaning and [pg897] scope" of the notion of special circumstances.FN25 The terms of Article 6 indeed suggest that there is considerable particularity in specifying continental shelf boundaries between adjacent states. The difficulty in formulating exact rules for such boundaries simply reflects the general lack of international principles for determining boundaries between the land areas of various states. Although there have been numerous boundary disputes in the history of international relations, nearly all have turned on "special circumstances." Article 6 extends this particularity to undersea land masses between adjacent states and, although it refers to the principle of equidistance, it qualifies this both by the obligation of agreement and the preface "unless another boundary line is justified by special circumstances." The question then is, justified by whom? Certainly not by the parties, since they have, at this point, failed to reach agreement. 
But then, if the justification is up to a court or an arbitral tribunal, we may surely at least one party to plead special circumstances in every case that arises. A concave coast, for instance, might be pleaded as a special circumstance! If such be the reality, then the entire provision is sufficiently open-ended as to cast grave doubt on its capacity to generate a universal rule of law of equidistance.

After considering the form in which Article 6, paragraph 2, was cast, the Court looked at the structure of the convention as a whole. The first paragraph of Article 12 provides:

At the time of signature, ratification or accession, any state may make reservations to articles of the Convention other than to Articles 1 to 3 inclusive.

Thus the substantive provisions of the convention (Articles 1 through 7) are divided into two categories: Articles 1 to 3 which possess a "norm-creating character" FN26 and Articles 4 to 7 having a "different and less fundamental status."FN27 This distinction, concluded the Court, adds to the evidence that Article 6 was probably not intended on the face of the treaty to be of a norm-creating character.

The foregoing structural argument should not be carried too far. For instance, Judge Ammoun in a concurring opinion states that the treaty-given power of reservations to Articles 6 implies the absence of opinio juris for "it is self-evident that a rule cannot be felt to be binding when the right not to apply it is reserved."FN28 But this argument proves too much, for, as Judge Morelli observes in dissent, "the power to make reservations is entirely compatible with the character of a convention or of a particular rule contained in a convention."FN29 Yet Judge Morelli's argument in turn is framed too broadly, for evidently the Continental Shelf

Convention manifested a distinction between the three and the following four articles; the latter were given a ease of reservation which tends to bear out the Court's argument. Parenthetically, the dissenting [pg898] judges might have examined for comparison the other Geneva Conventions of 1958: the Convention on the Territorial Sea and Contiguous Zone,FN30 the Convention on the High Seas,FN3l and the Convention on Fishing and Conservation of the Living Resources of the High Seas.FN32 Although each of these also begins with articles of generalized norms and then moves into particulars, none of them distinguish between those two classes for purposes of reservations, while the Fishing and Conservation Convention does distinguish on an entirely different basis (excluding from reservation certain articles in the body of the treaty dealing with procedures for the settlement of disputes under the convention). Such a comparison tends to throw some doubt upon the Court's categorization of the Continental Shelf Convention, though one might reply that the latter distinction between norm-creating provisions and special provisions is at least a plausible division and tends to add weight to the non-generalizable form in which Article 6 of that convention is couched.

Thus the World Court has, with precision and specificity, spelled out a methodology for determining distinctions between provisions in treaties as to their norm-creating customary law effect. Both the form in which the provision is couched, and the structure of the treaty (as evidenced in this case by the exclusion of certain articles from reservation) must be examined with care. Most importantly, the Court has clearly come down on the side of those who contend that provisions in treaties can generate rules of customary international law. 
The Court's remaining observations with respect to the alleged norm-creating character of the equidistance principle in Article 6 are unfortunately less convincing and considerably ambiguous. The Court refers to "other elements usually regarded as necessary before a conventional rule can be considered to have become a general rule of international law...."FN33 First, are the 39 states parties to the convention sufficiently wide-spread and representative in number? The Court answers that "the number of ratifications and accessions so far secured is, though respectable, hardly sufficient."FN34 Second, has there been sufficient passage of time since the convention? The Court casts doubt upon the sufficiency of ten years since the signing and less than five since the convention came into force in June, 1964. The difficulty with these observations, apart from the obvious drawback that their vagueness appears to be an aspect of judicial discretion rather than legal requirement, is that they would apply equally to all the provisions of the Continental Shelf Convention. Yet the Court itself with no hesitation found that the first three articles were norm-defining or norm-creating in character. This inconsistency suggests that the number of parties and the time factors were more in the nature of make-weight arguments than analytical distinctions. Roughly the same may be said of the final string in the Court's bow - that state practice [pg899] subsequent to the convention lacks the kind of uniformity necessary to show a general recognition that a rule of law is involved. Though The Netherlands and Denmark cited "certain cases_-not a great number" FN35 in which the equidistance principle was used, and though the Court admitted that these cases contained some evidential value,FN36 it simply concluded that the cases were inconclusive and insufficient. Of course, to the extent that these remaining observations by the Court appear unpersuasive, the doctrine of manifest intent assumes increased importance as the true basis for the holding.

\section{Shortcomings in The More Traditional ApProACH}

The rule of manifest intent that has just been examined does not draw a distinction between the manifest intent to create new law and the manifest intent to declare existing law. Rather, as we have seen, the Court's test is simply that if there is a provision in a treaty that is generalizable into a rule of customary law, then we must look to its form and structure within the treaty to see if there is a manifest intent that it be of a norm-creating character. The norm thus created may simply reinforce a pre-existing norm of customary law, or it may sharpen it or define it more precisely, or indeed it may create a new norm either in an area where a rule had not existed or in an area where a pre-existing rule is supplanted. The Court thus recognizes the fact that the conclusion of a treaty is a step of international legal significance taken by two or more states, an event on the same juridical basis as a practice of these two or more states that would normally have constituted a component of customary law. Not only is there a definite meeting of the minds in a treaty (as we infer from an act involving two or more states that constitutes practice for the purposes of customary law), but also there is the clear articulation of a rule of law that gives the treaty a special impetus toward formulating a general rule. A great many rules of customary international law, perhaps even the majority, had their origin in treaties,FN37 and the World Court itself in several cases has used treaties for evidence of rules of law held binding upon non-parties.FN38

[pg900] A valuable and meticulous essay published prior to the North Sea Continental Shelf decision may be said to represent the traditional view on the relation of provisions in 
treaties to customary law.FN39 In it Professor Baxter argues that only those treaties which declare existing customary law may be cited as evidence of customary law, while treaty provisions attempting to create new law or to contribute to its progressive development are not in themselves valid evidence of the state of international law. There are three areas which may be searched to help draw the distinction with respect to any treaty provision between a declaratory or innovative function: the face of the treaty itself, the travaux preparatoires, and customary international law dehors the treaty. If the treaty on its face purports to be declaratory of existing law, then there is a presumption in that direction, although, as Professor Baxter notes, this rule gives rise to possible "abuse" in terms of "self-serving words of declaration" stating that the treaty is declaratory of existing law in order to give it "an influence in customary law that it would lack if these words were not inserted."FN40 Thus we have to look beyond the treaty, beyond manifest intent to actual intent. But are the travaux helpful in this respect? Professor Baxter cogently argues that it is very difficult to extract anything unambiguous from travaux about intent to declare or to innovate, and to his arguments it might be added that negotiators will often enter into the record statements that their proposed wording or drafts should be accepted by the other side because they accurately reflect existing law. But surely there is a negotiating utility in seeming to depart the least from existing law as fewer concessions will have to be made by taking such a position. Therefore such statements in the travaux may be at least as self-serving as similar statements on the face of a treaty.

Thus Professor Baxter resorts finally to customary law dehors the treaty to show whether the treaty declares existing law or constitutes an innovation. There are numerous excellent examples in his articles of treaties cited as sources of international law, and as to each of these he examines the customary law apart from the treaty. When the independent customary law is in accord with the treaty, or in some cases when it at least does not conflict with it, Professor Baxter accepts the judicial result that the treaties were properly used as evidence of customary law. When the customary [pg901] law apart from the treaty is in conflict with the treaty rule, however, Professor Baxter is less willing to accept the soundness of the judicial result.

But the basic problem is that resorting to customary law dehors the treaty in order to prove whether the treaty declares such law or derogates from it seems to render valueless the treaty itself. For in the latter case, where the treaty derogates from the law, Professor Baxter says that the law and not the treaty provision controls. And in the former case, where the treaty simply declares existing law, the proof needed to demonstrate what existing law is apart from the treaty should quite suffice without any additional need of citing the treaty. In short, Professor Baxter's arguments appear to be directed toward the issue whether a treaty itself happens to coincide with existing law or depart from it, and not whether there are any lawcreation consequences for either alternative. His method of analysis would not, I suggest, be of much help to counsel on either side of a case in which a treaty provision was relied upon in support of an allegation of a rule of customary law to the same substantive effect. Nor would it seem to help a court having the burden of finding a rule of international law when, as in the Nottebohm case,FN41 it is extraordinarily difficult to find any state practice apart from various treaties. Further, inasmuch as the International Law Commission has long since given up the task of attempting to differentiate between codification and progressive development in its work on draft multilateral conventions, and insofar as most treaties at present purport to declare 
existing law rather than to signal their departure from it, the distinction suggested by Professor Baxter might diminish in objective importance even if the difficulties in establishing it could be surmounted.

Professor Baxter's essay reflects the caution with which scholars of international law have approached the issue of treaty generation of customary rules of law. As perhaps the most cogent statement of the traditional view, it stands as a target for commentary when perhaps it would have been fairer, though less efficient, to comment upon the writings of others who share his approach. The traditional view, however, does not appear sufficient to explain the origin in treaties of many rules of international law, the use of treaties by the World Court, and especially the new approach of intent in the 1969 case of the North Sea Continental Shelf.

\section{CONCLUSION}

I have argued elsewhereFN42 that a general theory of how customary international law comes into being must be (a) internally consistent, (b) general without being vague, (c) in accord with all the inductive evidence, (d) simple, (e) objectively determinable, and (f) claimoriented. The degree of confusion in the international law literature relative to the formation of custom can no longer be acceptable in a shrinking world [pg902] where legal lines must have the necessary clarity to minimize mistakes leading to military conflicts, in turn leading to possible nuclear escalation. States, as well as scholars, have a basic interest in clarifying the theoretical underpinnings of international legal theory in order that they may better determine where the substantive legal lines are in fact drawn. A clear boundary, like a good fence, makes good neighbors.

The recent Continental Shelf decision of the World Court is an important step toward this goal. It deals only with one area of formation of customary law: the generation by treaty of customary norms. But in that area the Court takes a major step of freeing itself from the inconclusive hunting of subjective intent, and instead sets up an objectively determinable test: the rule of manifest intent. By looking both at the form in which a treaty provision is couched, and the structure of the treaty itself, the generalizability or non-generalizability of the provision, and hence its impact upon customary law, may be scientifically determined.

\section{FOOTNOTES}

*Northwestern University.

**Numbers in the format "pg892” etc. refer to the pagination of the original publication.

FN1 [1969] I.C.. Rep. 3; 63 A.J.I.L. 591 (1969); 8 Int. Legal Materials 340 (1969).

FN2 The equidistance line leaves to a coastal state "all those portions of the Continental Shelf that are nearer to a point on its own coast than they are to any point on the coast of" the adjacent coastal state. [1969] I.C.J. Rep. 3, at 18. 
FN3 Text in 52 A.J.I.L. 858 (1958).

FN4 [1969] I.C.J. Rep. 3, at 26.

FN5 Ibid. at 18.

FN6 Ibid.

FN7 Ibid. at 24.

FN8 Ibid. at 24-25.

FN9 Ibid. at 28.

FN10 Ibid. at 36.

FN11 Fuller, The Problems of Jurisprudence 9 (temp. ed., 1949).

FN12 Although tangential to the present essay, it may be noted that the Court grounded the necessity for an equitable result in the customary international law of the continental shelf, particularly in the notion of "equitable principles" in the Truman Proclamation of 1945, one of the earliest components of the international law on this subject. [1969] I.C.J. Rep. 3, at 33.

FN13 I have attempted to spell this out in detail elsewhere. See D'Amato, "Treaties as a Source of General Rules of International Law" 3 Harvard Int. Law J. 1 (1962). Cf. idem, "Legal Aspects of the French Nuclear Tests," 61 A.J.I.L. 66, 76-77 (1967).

FN14 A fourth possibility considered by the Court, but irrelevant to the present essay, is whether an equidistance rule exists solely in customary or natural law. The Court decided this question in the negative.

FN15 "[T] his contention. . . clearly involves treating [Article 6] as a norm-creating provision which has constituted the foundation of, or has generated a rule which, while only conventional or contractual in its origin, has since passed into the general corpus of international law ...." [1969] I.C.J. Rep. 3, at 42.

FN16 Ibid at 43.

FN17 Ibid. at 42.

FN18 Ibid. at 40, 43.

FN19 See D'Amato, "The Concept of Special Custom in International Law," 63 A.J.I.L. 211 (1969).

FN20 [1969] I.C.J. Rep. 3, at 43. 
FN21 Ibid.

FN22 Article 6, par. 2, Convention on the Continental Shelf, 52 A.J.I.L. 858, 860 (1958).

FN 23 See Schwarzenberger, "International Jus Cogens?", 43 Texas Law Rev. 455 (1965); Riesenfeld, Jus Dispositivum and Jus Cogens in International Law: In the Light of a Recent Decision of the German Supreme Constitutional Court," 60 A.J.I.L. 511 (1966); Verdross, Jus Dispositivum and Jus Cogens in International Law," 60 A.J.I.L. 55 (1966).

FN24 [1969] I.C.J. Rep. 3, at 43.

FN25 Ibid.

FN26 Ibid.

FN27 Ibid. at 41.

FN28 Ibid. at 131.

FN29 Ibid at 199.

FN30 52 A.J.I.L. 834 (1958).

FN31 Ibid. at 842.

FN32 Ibid. at 851.

FN33 [1969] I.C.J. Rep. 3, at 43.

FN34 Ibid.

FN35 Ibid at 45.

FN36 Ibid. at 46.

FN37 See D'Amato, loc. cit. note 13 above, and also the many examples given in Baxter "Multilateral Treaties as Evidence of Customary International Law," 41 Brit. Yr. Bk. Int. Law 275 (1965-1966). In "The Treaty as a Law-Declaring and Custom-Making Instrument," 22 Egyptian Rev. Int. Law 51, 73-74 (1966), Dr. Shihata claims that state practice with respect to the exemption from capture as prize of war of coastal fishing vessels did not originate in treaties. However, a closer reading of the case he cites to prove this point, The Paquete Habana, 175 U.S. 677, 687 (1900), clearly demonstrates the contrary. The first two precedents in that case were treaties concluded between the monarchs of France and England in 1403 and 1521, recited in orders of the King of England as authority for his implementing legislation. 
FN38 Notebohm Case, Second Phase, [1955] I.C.J. Rep. 4, 22-23 (Bancroft treaties, Pan American Convention of 1906, and Hague Convention of 1930, the only specific references to any precedent in the entire opinion, and all not involving the parties to the case); AngloNorwegian Fisheries Case, [1951] I.C.J. Rep. 116, 131 (treaties and conventions divided as to ten-mile rule for bays); S.S. Wimbledon, P.C.I.J., Ser. A, No.1, at 15, 28 (1923) (Suez and Panama treaties as precedents for a customary law of interpretation of the Versailles Treaty); International Commission of the Oder, P.C.I.J., Ser. A, No. 23, at 5, 27 (1929) (international river law developed by "subsequent conventions"); Mavrommatis Case, P.C.I.J., Ser. A, No.2, at 6, 35 (1924) (arbitration treaties used for a customary law of treaty-interpretation for the Mandate treaty in the case).

FN39 Baxter, loco cit. note 37 above.

FN40 Ibid. at 290. It may be noted that, although Professor Baxter seems to confine his remarks to multilateral conventions, no substantive distinction is offered between those and bilateral treaties. It would not seem that a bilateral treaty is different in kind from a multilateral treaty; only the number of parties is smaller. The Bancroft treaties, cited in the Nottebohm Case, note 38 above, were a series of bilateral treaties containing substantially similar provisions.

FN41 Second Phase, [1955] I.C.J. Rep. 4.

FN42 See D'Amato, "Wanted: A Comprehensive Theory of Custom in International Law," 4 Texas Int. Law Forum 28, 36-40 (1968). 